\title{
Cold acclimation increases levels of some heat shock protein and sirtuin isoforms in threespine stickleback
}

Laura E. Teigen, Julieanna I. Orczewska, Jessica McLaughlin and Kristin M. O’Brien *, Institute of Arctic Biology, University of Alaska, Fairbanks, AK 99775, *Corresponding author:

kmobrien@alaska.edu, ph: 907-474-5311, fax 907-474-7666 


\begin{abstract}
Molecular chaperones [heat shock proteins (HSPs)] are known to increase in response to rapid changes in temperatures, but long-term acclimation to cold temperature may also warrant elevations in HSPs. In fishes, cold acclimation increases mitochondrial density and oxidative stress in some tissues, which may increase demand for HSPs. We hypothesized that levels of HSPs, as well as sirtuins (SIRTs), NAD-dependent deacetylases that mediate changes in metabolism and responses to oxidative stress (including increases in HSPs), would increase during cold acclimation of threespine stickleback (Gasterosteus aculeatus). Transcript levels of $h s p 70, h s c 70, h s p 60$ and $h s p 90-\alpha$, sirts 1-4, as well as protein levels of HSP60, HSP90 and HSC70 were quantified in liver and pectoral adductor muscle of threespine stickleback during cold acclimation from $20^{\circ} \mathrm{C}$ to $8{ }^{\circ} \mathrm{C}$. In liver, cold acclimation stimulated a transient increase in mRNA levels of $h s p 60$ and $h s c 70$. Transcript levels of sirt 1 and sirt 2 also increased in response to cold acclimation and remained elevated. In pectoral muscle, mRNA levels of $h s p 60, h s p 90-\alpha$, hsc70 and sirtl all transiently increased in response to cold acclimation, while levels of sirts2-4 remained constant or declined. Similar to transcript levels, protein levels of HSC70 increased in both liver and pectoral muscle. Levels of HSP90 also increased in liver after 4 weeks at $8{ }^{\circ} \mathrm{C}$. HSP60 remained unchanged in both tissues, as did HSP90 in pectoral muscle. Our results indicate that while both HSPs and SIRTs increase in response to cold acclimation in stickleback, the response is tissue and isoform specific, likely reflecting differences in metabolism and oxidative stress.
\end{abstract}

\title{
Key Words
}

cold acclimation, fish, heat shock proteins, metabolism, oxidative stress, sirtuins 


\section{Introduction}

Molecular chaperones assist with the folding and assembly of proteins (Hartl, 1996). Chaperones were first identified as proteins induced by heat stress, and so aptly named heat shock proteins (HSPs) (reviewed by Lindquist, 1986) We now know that many HSPs are induced by a variety of stressors. Virtually any perturbation of the cellular milieu (ie; oxidative, osmotic, temperature, chemical stress) will lead to an increase in levels of HSPs (Lindquist, 1986). Moreover, chaperones not only assist with folding proteins, both those produced de novo and denatured by stress, but also assemble multimeric proteins, participate in signaling pathways, and assist with the degradation of proteins by the ubiquitin- proteasome system (Kim et al., 2013). The different families of HSPs are categorized according to molecular mass and include HSP100, HSP90, HSP70, HSP60, and small HSPs (Mogk et al., 2001).

Changes in levels of HSPs have been well characterized in fishes and other ectotherms in response to acute temperature stress (ie; Dietz and Somero, 1992; Donaldson et al., 2008; Feder and Hofmann, 1999; Todgham et al., 2005; Tomanek and Somero, 1999). Yet, to date, the role of HSPs in mediating acclimatory responses to decreases in temperature in fishes has not been fully explored. Nevertheless, many aspects of acclimation to cold temperature may warrant elevations in HSPs, including the proliferation of mitochondria, defenses against oxidative stress, and preventing thermal denaturation of proteins.

Temperate fishes may endure seasonal changes in temperature as great as $30^{\circ} \mathrm{C}$, stimulating metabolic remodeling to maintain ATP production (Elliott and Elliott, 2010; Hochachka and Somero, 2002). As temperature decreases, levels of metabolic enzymes often increase to offset the depressive effects of cold temperature on the catalytic rate of enzymes 
(Egginton and Sidell, 1989; Johnston and Maitland, 1980; Orczewska et al., 2010). Concurrent with an increase in aerobically-poised enzymes in some tissues, is an increase in the percent cell volume displaced by mitochondria (Egginton and Sidell, 1989; Orczewska et al., 2010).

Mitochondrial biogeneisis and increases in levels of aerobic metabolic enzymes in response to cold acclimation may increase demand for HSPs. The mitochondrial genome encodes only 13 of the estimated 1,400 mitochondrial proteins (Baker et al., 2012; Lotz et al., 2013; Taylor et al., 2003). The majority of mitochondrial proteins are synthesized on cytosolic ribosomes and imported into mitochondria. Isoforms of HSP/HSC70 and HSP90 are located in the cytosol where they interact with the translocase of the outer mitochondrial membrane (TOM) to facilitate protein import (Kang et al., 1990; Lithgow et al., 1993; Young et al., 2003). Imported proteins are then refolded by mitochondrial isoforms of HSP/HSC70 and HSP60 within the mitochondrial matrix (Cheng et al., 1989; Craig et al., 1989; Mogk et al., 2001).

Cold acclimation also promotes oxidative stress in some fish tissues. Protein carbonyls, one form of protein oxidation and an indirect measure of ROS, transiently increase during cold acclimation and are 2.3-fold higher in the liver of threespine stickleback cold acclimated to $8{ }^{\circ} \mathrm{C}$ for 4 weeks compared to those at $20{ }^{\circ} \mathrm{C}$ (Kammer et al., 2011). Similarly, both lipid peroxidation and protein carbonyl levels are 1.5-fold higher in livers of eelpout (Zoarces viviparous) acclimated to $6{ }^{\circ} \mathrm{C}$ compared to animals at $12{ }^{\circ} \mathrm{C}$ (Heise et al., 2007). Increases in levels of oxidized macromolecules during cold acclimation suggest cold temperature may compromise protein integrity. Consistent with this, activity of the $20 \mathrm{~S}$ proteasome is 1.3 -fold higher in white muscle of juvenile spotted wolffish (Anarhichas minor) acclimated to $4{ }^{\circ} \mathrm{C}$ compared to wolffish at $8{ }^{\circ} \mathrm{C}$, and 1.8 -fold higher compared to animals at $12{ }^{\circ} \mathrm{C}$ (Lamarre et al., 2009). Higher rates of protein degradation at cold temperature may warrant increased rates of protein synthesis and 
levels of HSPs to assist with targeting damaged proteins to the proteasome and with folding newly synthesized proteins. HSPs are also essential for preventing thermal denaturation and aggregation of proteins that may occur as temperature decreases. Studies in cold-adapted fishes support this conjecture. The Antarctic fishes Trematomus bernacchii, Trematomus pennellii and Pagothenia borchgrevinki have higher levels of ubiquitinated proteins and levels of HSP70 compared to the New Zealand species Bovichtus variegatus and Notothenia angustata (Place et al., 2004; Todgham et al., 2007).

The molecular pathways mediating metabolic remodeling and responses to oxidative stress during cold acclimation of fishes are largely unknown. Sirtuins (SIRTs), a family of highly conserved NAD-dependent deacetylases and ADP-ribosyltransferases mediate both pathways in mammals, and also induce expression of HSPs, potentially providing a unifying explanation for the molecular drivers of cold acclimation in fishes (Brenmoehl and Hoeflich, 2013; Hori et al., 2013; Westerheide et al., 2009).

In mammals, there are seven sirtuins, SIRTs1-7, localized to different compartments in the cell. SIRT1, SIRT6, and SIRT7 are found in the nucleus, whereas SIRT2 is found in the cytoplasm, and SIRTs 3-5 in mitochondria (Michishita et al., 2005). SIRTs function as energy sensors, increasing activity as $\mathrm{NAD}^{+}$levels increase, and consequently, are central mediators of metabolism (Ahn et al., 2008; Gambini et al., 2011; Osborne et al., 2013). SIRTs also enhance defenses against oxidative stress. SIRT2 deacetylates the O class of forkhead box transcription factors (FoxO), which drives increases in the key antioxidants, superoxide dismutase and catalase (Wang et al., 2007). Additionally, SIRT1 deacetylates the transcriptional regulator of HSP70, HSF1, prolonging its binding to the HSP70 promoter (Westerheide et al., 2009). 
Few studies to date have investigated the role of sirtuins in mediating responses to changes in temperature in ectotherms. A study by Han et al. (2013) showed that sirtuins increase concurrently with HSPs in response to acute heat stress in the intertidal limpet Cellana toreuma, suggesting sirtuins may regulate levels of HSPs. Transcript levels of $h s p 70, h s p 90$, ampk, and sirtl all increased in response to heat shock to $40{ }^{\circ} \mathrm{C}$ in C. toreuma (Han et al., 2013).

We hypothesized that levels of HSPs and SIRTs would change in response to cold acclimation of threespine stickleback. Previous studies in our lab have shown that the molecular basis of aerobic metabolic remodeling differs between pectoral muscle and liver in threespine stickleback in response to cold acclimation. In pectoral muscle, mitochondrial biogenesis occurs, whereas in liver, concentrations of aerobic metabolic enzymes increase in the absence of mitochondrial biogenesis (Orczewska et al., 2010). Additionally, in liver but not pectoral muscle, levels of oxidized proteins increase during cold acclimation (Kammer et al., 2011). These differences may be reflected in differences in the expression and levels of HSP and sirtuin isoforms. To characterize changes in patterns of expression of HSPs and SIRTs, stickleback were cold acclimated from $20^{\circ} \mathrm{C}$ to $8{ }^{\circ} \mathrm{C}$ for 9 weeks or maintained at $20{ }^{\circ} \mathrm{C}$ for 9 weeks. Transcript levels of $h s p 90-\alpha, h s p 60, h s p 70, h s c 70$, and sirts1-4, and protein levels of HSP60, HSP90, and HSC70 were quantified in pectoral muscle and liver tissue in stickleback harvested during cold acclimation and in animals held at $20^{\circ} \mathrm{C}$.

\section{Materials and methods}

\subsection{Animals}

All protocols for the treatment and use of animals were approved by the University of Alaska Fairbanks Institutional Animal Care and Use Committee (135490-2 and 135490-7). 


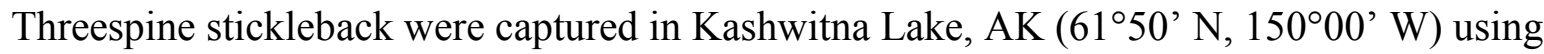
minnow traps in August 2007 for transcript measurements and in August 2013 for measuring levels of HSP proteins. Water temperature at time of capture was $16.5^{\circ} \mathrm{C}$ in 2007 and $13.1^{\circ} \mathrm{C}$ in 2013. Fish were transported to the University of Alaska Fairbanks and maintained in filtered, aerated, $114 \mathrm{~L}$ aquaria filled with water and $0.35 \%$ Instant Ocean. In 2007, fish were maintained for 12 weeks on a $10: 14 \mathrm{~h}$ light:dark cycle at $20^{\circ} \mathrm{C}$ and fed bloodworms and brine shrimp twice daily. After 12 weeks, the first group of fish was harvested $\left(20^{\circ} \mathrm{C}\right.$ start). Remaining fish were then either cold acclimated to $8{ }^{\circ} \mathrm{C}$ or maintained at $20{ }^{\circ} \mathrm{C}$ for 9 weeks. After the initial harvest on day 0 (start), the temperature was decreased for cold-acclimated animals to $15^{\circ} \mathrm{C}$ on day 1 ,

$10{ }^{\circ} \mathrm{C}$ on day 2 , and $8{ }^{\circ} \mathrm{C}$ on day 3 . Fish were held at $8{ }^{\circ} \mathrm{C}$ for an additional 9 weeks. Between 20 and 40 animals were harvested each day before the temperature was decreased and after 1, 4, and 9 weeks at $8{ }^{\circ} \mathrm{C}$. The acclimation regime was similar in 2013 except that animals were held for 20 weeks at $20^{\circ} \mathrm{C}$ before beginning cold acclimation and harvested at the start $\left(20^{\circ} \mathrm{C}\right)$, after 4 weeks and 9 weeks at $8{ }^{\circ} \mathrm{C}$, and at $20^{\circ} \mathrm{C}$ for an additional 9 weeks. All animals were harvested at the same time each morning before feeding to avoid the potentially confounding effects of circadian rhythms on gene expression (Podrabsky and Somero, 2004). Fish were netted, immediately frozen in liquid nitrogen and stored at $-80{ }^{\circ} \mathrm{C}$. Body mass, length, and masses of liver and oxidative muscles were recorded for each individual.

\subsection{Quantitative real-time PCR}

RNA was isolated from pectoral muscle and liver tissue using the RNeasy Fibrous Tissue Mini-kit (Qiagen), with minor modifications to increase yield, as follows. Samples were treated 
twice with DNase I: once for 25 min and again for 20 min. Complimentary DNA (cDNA) was synthesized using TaqMan reverse transcription reagents (Applied Biosystems). Each reaction contained $5.5 \mathrm{mM} \mathrm{MgCl}_{2}, 2.5 \mu \mathrm{M}$ random hexamers, $2 \mathrm{mM}$ deoxynucleotide triphosphates (dNTPs), 4 units of RNase inhibitor, 37.5 units of reverse transcriptase, and 200 ng RNA. For each sample, a control was also synthesized lacking reverse transcriptase (-RT). cDNA synthesis was performed using an iCycler (Bio-Rad) programmed at $25^{\circ} \mathrm{C}$ for $10 \mathrm{~min}, 48^{\circ} \mathrm{C}$ for $30 \mathrm{~min}$, and $95^{\circ} \mathrm{C}$ for $5 \mathrm{~min}$.

Gene specific primers were designed using Primer Express v3.0 software (Applied Biosystems) with either a forward or reverse primer of each set annealing over a splice site when possible to ensure genomic DNA was not amplified (Table 1). Sequence information was obtained from Ensembl (www.ensembl.org). Several sequences exist for each target gene; therefore, primers were selected based on homology with other closely-related fish species (supplementary material Fig. S1-S4). Transcript levels of hsp90- $\alpha$, hsp70, hsp 60, hsc70, sirtl, sirt2, sirt3, sirt4, $18 S$, and $E F-1 \alpha$ were measured using quantitative real-time PCR (qRT-PCR) and an ABI PRISM 7900 HT Sequence Detection System (Applied Biosystems) as described previously (Kammer et al., 2011; Orczewska et al., 2010). Each reaction contained 1X Power SYBR Green PCR Master Mix, $0.3 \mu \mathrm{M}$ of each forward and reverse primer, and $5 \mathrm{ng}$ of cDNA template, except for $h s p 70$ and $h s c 70$ in pectoral muscle and $h s p 90-\alpha$, and $h s p 70$ in liver where gene expression was low and $10 \mathrm{ng}$ cDNA template was required to detect transcripts. In addition, only $1 \mathrm{ng}$ of cDNA was used in each reaction to quantify levels of $18 S$. Reaction efficiency and relative gene expression levels were determined using a standard curve. Optimum primer concentration was determined by testing efficiency using $200 \mathrm{nM}, 300 \mathrm{nM}$ and $400 \mathrm{nM}$ of primers. Complementary DNA from animals harvested at all temperatures and time points was 
pooled and serially diluted to create a standard curve for quantifying relative transcript levels. Separate standard curves were prepared for each gene and tissue type. Primer efficiency was determined from the slope of the standard curve. A dissociation curve was run for each reaction at $95{ }^{\circ} \mathrm{C}$ for $15 \mathrm{~s}, 60^{\circ} \mathrm{C}$ for $15 \mathrm{~s}$, and $95^{\circ} \mathrm{C}$ for $15 \mathrm{~s}$ (slow ramp) to verify the specificity of each primer set. Two types of controls were used: one for each primer set in which the cDNA template was replaced with an equal volume of Milli $\mathrm{Q} \mathrm{H}_{2} \mathrm{O}$. The second control, which was run in parallel with each sample, contained template from the cDNA synthesis reactions in which the reverse transcriptase (RT) was omitted. Both of these controls allowed us to identify and omit samples containing contaminated genomic DNA. Relative transcript levels of $h s p / h s c$ and sirt genes were normalized to transcript levels of $E F-1 \alpha$ in pectoral muscle and $18 S$ in liver tissue, which were previously determined to be suitable housekeeping genes (Orczewska et al., 2010). Only samples with critical threshold (CT) values greater than 4 CTs away from their corresponding - RT controls were included in the final analyses. All measurements were made in triplicate in 6-11 individuals per tissue and time point $\left(20^{\circ} \mathrm{C}\right.$ start, $15^{\circ} \mathrm{C}, 10^{\circ} \mathrm{C}, 8^{\circ} \mathrm{C}, 8^{\circ} \mathrm{C}$ week $1,8{ }^{\circ} \mathrm{C}$ week $4,8{ }^{\circ} \mathrm{C}$ week 9 and $20^{\circ} \mathrm{C}$ week 9$)$.

\subsection{Western blotting}

Livers were homogenized in 4 volumes and pectoral muscles in 8 volumes of ice-cold buffer (250 mM Tris·HCl, 10 mM EDTA, 10 mM EGTA, pH 7.4). Homogenates were centrifuged for $5 \mathrm{~min}$ at $500 \mathrm{~g}$ and supernatant collected. Protein concentration was determined by a Bradford assay (Bradford, 1976). Tissue homogenates were resuspended in SDS sample buffer (20 mM NaPO 4 , 8\% glycerol, $40 \mathrm{mM}$ dithiothreitol, 0.025\% Bromophenol Blue, 4\% SDS, 
$\mathrm{pH}$ 6.8) at a concentration of $8 \mathrm{ug} \mathrm{uL} \mathrm{L}^{-1}$ for liver and $4 \mathrm{ug} \mathrm{uL} \mathrm{L}^{-1}$ for pectoral adductor muscle. Liver and pectoral muscle samples from animals harvested at $20{ }^{\circ} \mathrm{C}$ start, $8{ }^{\circ} \mathrm{C}$ week $4,8{ }^{\circ} \mathrm{C}$ week 9 and $20^{\circ} \mathrm{C}$ week $9(100 \mu \mathrm{g}$ each) were separated on $10 \%$ polyacrylamide gels. Each gel contained samples from each temperature and time point. HSP protein levels prior to week 4 were not measured because we anticipated that changes in protein levels would occur more slowly than changes in transcript levels. Proteins were transferred to $0.20 \mu \mathrm{m}$ nitrocellulose membrane using a semi-dry transfer apparatus (GE Healthcare) set at $0.8 \mathrm{~mA} \mathrm{~cm}^{-1}$ of mask opening for $1.5 \mathrm{~h}$ and using transfer buffer containing $25 \mathrm{mM}$ Tris, $192 \mathrm{mM}$ glycine, $0.1 \%$ SDS, and $20 \%$ methanol. Membranes were blocked for at least $1 \mathrm{~h}$ in Blotto (5\% nonfat dry milk in phosphate buffered saline (PBS) with $0.1 \%$ Tween-20) at room temperature and washed in $0.1 \%$ PBS-Tween as follows: 2 quick rinses, one rinse for $15 \mathrm{~min}$, and twice for $5 \mathrm{~min}$ each. Membranes were incubated overnight at $4{ }^{\circ} \mathrm{C}$ in either 1:2500 anti-HSC70 salmon (StressMarq SPC-303D) or both 1:5000 anti-HSP60 salmon (StressMarq SMC-111A/B) and 1:2500 antiHSP90 salmon (StressMarq SMC-107A/B). Following incubation, the membranes were washed again as described above and incubated in either 1:5000 anti-rabbit IgG (whole molecule) peroxidase antibody produced in goat (Sigma A6154) or 1:2500 anti-mouse IgG (whole molecule) peroxidase antibody produced in rabbit (Sigma A9044), respectively, for $2 \mathrm{~h}$ at room temperature. After a final wash as described above, membranes were developed using Amersham ECL Prime Western Blotting Detection Reagent kit (GE Healthcare) following manufacturer's instructions and visualized using an AlphaImager 3400 CCD camera and AlphaEaseFC software v4.0.1 (ProteinSimple). Protein density was quantified using ImageQuant TL v.8.1 (GE Healthcare). All measurements were made in 4-6 individuals per tissue and temperature treatment. Relative levels of each HSP were normalized to the average HSP level in 
individuals at $20^{\circ} \mathrm{C}$ (start) for each tissue. HSP70, using the antibody anti-HSP70 (salmon) (StressMarq SPC-313D) could not be detected in either tissue.

\subsection{Statistical analyses}

Significant differences in gene expression among stickleback held at different temperatures and collected at different time points were determined using a Kruskal-Wallis test followed by a post hoc Tukey's honestly significant difference test for multiple comparisons using JMP v7.0.2 (SAS). Significant differences in HSP protein levels were determined using an ANOVA followed by a post hoc Tukey's test except for levels of HSC70 in pectoral adductor muscle. These data had unequal variance as determined by a Levene's test and so means were compared using a Welch's ANOVA. Data were log transformed as necessary to maintain assumptions of normality as determined by a Shapiro-Wilk's test. Significance was set at $\alpha<$ 0.05 except for analysis of HSC70 levels in pectoral muscle in which $P<0.10$ because of the small sample size $(\mathrm{N}=4)$.

\section{Results}

\subsection{Physical characteristics}

Body mass and length increased during the time period of the experiment but there was no effect of temperature on physical characteristics (Table 2). There was no difference in length, body mass or condition index between animals held at $20^{\circ} \mathrm{C}$ for 9 weeks and animals held at 8 ${ }^{\circ} \mathrm{C}$ for 9 weeks, nor were there any differences in the condition index among animals collected at different time points and temperatures during the experiment $(P>0.05$; Table 2$)$. 


\subsection{Transcript levels of heat shock proteins}

Hsp60 mRNA levels increased significantly by day 3 of cold acclimation $\left(8^{\circ} \mathrm{C}\right)$ in liver and at this time were 3.3-fold higher compared to fish at $20{ }^{\circ} \mathrm{C}$ (start) and 7.9-fold higher than stickleback at $20^{\circ} \mathrm{C}$ for 9 weeks $(P<0.05$; Fig. 1A). Levels of $h s p 60$ transcripts decreased by week 4 of cold acclimation and by then, levels were equivalent to stickleback at $20{ }^{\circ} \mathrm{C}$ at the start and end of the acclimation period $(P>0.05$; Fig. 1A). Transcript levels of $h s p 90-\alpha$ were not consistently detected in liver (ie; most samples had a CT value $\leq 4 \mathrm{CT}$ values higher than the RT control). The efficiency of the primers was high (Table 1) and therefore we believe the inability to detect transcripts was due to the low abundance of the transcript.

In pectoral muscle, both $h s p 90-\alpha$ and $h s p 60$ mRNA levels increased by day 2 of cold acclimation $\left(10^{\circ} \mathrm{C}\right)\left(P<0.05\right.$; Fig. 1B). Hsp90- $\alpha$ transcripts were highest in stickleback at $8{ }^{\circ} \mathrm{C}$ (day 3) at which point levels were 4.4- and 3.5-fold higher than fish at $20{ }^{\circ} \mathrm{C}$ (start) and $20{ }^{\circ} \mathrm{C}$ for 9 weeks, respectively. $H s p 60$ mRNA levels were also highest in stickleback at $8^{\circ} \mathrm{C}$ (day 3) when levels were 7.3- and 4.9-fold greater than fish at $20^{\circ} \mathrm{C}$ (start) and $20^{\circ} \mathrm{C}$ for 9 weeks, respectively. By the end of the acclimation period, $h s p 60$ and $h s p 90-\alpha$ levels were equivalent between stickleback at $8{ }^{\circ} \mathrm{C}$ for 9 weeks and those at $20{ }^{\circ} \mathrm{C}$ for 9 weeks.

Hsc70 mRNA levels increased during cold acclimation in stickleback livers and were significantly greater in stickleback at $10^{\circ} \mathrm{C}$ (day 2) and at $8^{\circ} \mathrm{C}$ (day 3) compared to stickleback at $20{ }^{\circ} \mathrm{C}$ at the start of the acclimation period $(P<0.05$; Fig. $1 \mathrm{C}) . H s c 70$ mRNA levels were 7.8 fold higher in livers of stickleback at $10{ }^{\circ} \mathrm{C}$ than in fish at $20^{\circ} \mathrm{C}$ (start), and levels were 10.2-fold higher in livers of stickleback at $8{ }^{\circ} \mathrm{C}$ compared to stickleback at $20{ }^{\circ} \mathrm{C}$ (start). After 1 week of 
acclimation at $8{ }^{\circ} \mathrm{C}, \mathrm{Hsc} 70$ transcripts were equivalent to those in fish at $20^{\circ} \mathrm{C}$ (start) and in stickleback held at $20{ }^{\circ} \mathrm{C}$ for 9 weeks.

Similar to liver, $H s c 70$ mRNA levels increased in response to cold acclimation in pectoral muscle and were highest in animals at $8{ }^{\circ} \mathrm{C}$ (day 3) when levels were 4.8- and 2.3-fold greater than stickleback at $20{ }^{\circ} \mathrm{C}$ (start) and $20^{\circ} \mathrm{C}$ for 9 weeks, respectively $(P<0.05$; Fig. 1D). By week 4 of acclimation, $H s c 70$ transcripts decreased and were equivalent to those in animals at $20{ }^{\circ} \mathrm{C}$ for 9 weeks.

$H s p 70$ was not consistently detected in either tissue (ie; most samples had a CT value $\leq 4$ $\mathrm{CT}$ values higher than the $-\mathrm{RT}$ control). Primer efficiency was high (Table 1) so we believe the inability to detect the mRNA was due to low abundance of the transcript.

\subsection{Protein levels of heat shock proteins}

Although Hsp90- $\alpha$ transcript levels were not robustly expressed in the liver, HSP90 protein levels were high. Levels of HSP90 tended to increase in stickleback livers during cold acclimation and reached a maximum after 9 weeks at $8{ }^{\circ} \mathrm{C}$, at which time they were 5.7-fold higher than animals at $20{ }^{\circ} \mathrm{C}$ (start) $(P=0.001)$ and 1.7 - fold higher than animals at $20{ }^{\circ} \mathrm{C}$ after 9 weeks $(P=0.11$; Fig. 2a, b). Levels of HSP60 did not change in response to cold acclimation in liver or pectoral adductor muscle (Fig. 2A,B and C), nor did levels of HSP90 change in pectoral muscle in response to cold acclimation (Fig. 2A,C).

Levels of HSC70 increased in both liver and pectoral adductor muscle during cold acclimation. In liver, levels of $\mathrm{HSC} 70$ were significantly higher after 4 weeks at $8{ }^{\circ} \mathrm{C}$ compared to stickleback at $20^{\circ} \mathrm{C}$ (start) and higher in stickleback after 9 weeks of cold acclimation compared to stickleback at $20{ }^{\circ} \mathrm{C}$ (start and week 9; $P<0.05$; Fig 2D, E). In pectoral adductor 
muscle, levels of HSC70 were significantly greater in animals after 4 weeks of cold acclimation compared to those at $20^{\circ} \mathrm{C}$ (start and week 9; $P=0.074$; Fig 2D, F) but then decreased and by week 9 of cold acclimation were not significantly different than stickleback held at $20{ }^{\circ} \mathrm{C}$ for 9 weeks $(P>0.10$; Figs. 2 D,F).

\subsection{Transcript levels of sirtuins}

Transcript levels of sirt1 and sirt2 increased in liver of stickleback in response to cold acclimation $(P<0.05$; Fig. 3A). Sirt 1 mRNA levels were significantly higher in animals at 10 ${ }^{\circ} \mathrm{C}$ (day 2) and remained elevated throughout the cold acclimation period. Transcripts were highest in stickleback at $8{ }^{\circ} \mathrm{C}$ on day 3 when levels were 3.9 - and 2.5-fold greater compared to fish at $20{ }^{\circ} \mathrm{C}$ (start) and $20{ }^{\circ} \mathrm{C}$ for 9 weeks, respectively. Sirt 2 transcript levels increased significantly in stickleback livers by day 3 of cold acclimation $\left(8^{\circ} \mathrm{C}\right)$ and remained elevated throughout the acclimation period. Transcript levels were highest in stickleback at $8{ }^{\circ} \mathrm{C}$ for 4 weeks when levels were 2.6- and 1.7-fold greater than fish at $20{ }^{\circ} \mathrm{C}$ (start) and $20{ }^{\circ} \mathrm{C}$ for 9 weeks, respectively.

In pectoral muscle, sirt $1 \mathrm{mRNA}$ levels were significantly higher in stickleback at $8^{\circ} \mathrm{C}$ (day 3) compared to animals at $20{ }^{\circ} \mathrm{C}$ (start) and animals at $20{ }^{\circ} \mathrm{C}$ for an additional 9 weeks $(P<$ 0.05; Fig. 3B). Sirt1 transcripts were 3.2- and 3-fold higher in animals at $8{ }^{\circ} \mathrm{C}$ (day 3 ) compared to fish at $20{ }^{\circ} \mathrm{C}$ (start) and at $20{ }^{\circ} \mathrm{C}$ for an additional 9 weeks, respectively. Transcript levels of

sirt2 did not change significantly during cold acclimation in pectoral muscle $(P>0.05$; Fig. 3B).

In liver, sirt3 mRNA levels were significantly lower in animals on $8{ }^{\circ} \mathrm{C}$ (day 3 ) compared to $20^{\circ} \mathrm{C}$ (start) (Fig. 3C). Similarly, levels of sirt3 mRNA declined during cold acclimation in pectoral muscle and were 2.8 -fold lower at $8{ }^{\circ} \mathrm{C}$ for 4 weeks compared to fish at 
$20{ }^{\circ} \mathrm{C}$ (start) (Fig. 3D). Levels of sirt4 mRNA did not change in the liver or pectoral muscle of stickleback in response to cold acclimation $(P>0.05$; Fig. 3C,D).

\section{Discussion}

Results from this study show that transcript levels of some HSPs and SIRTs increase transiently during cold acclimation in stickleback, and that the pattern of expression of HSP and SIRT isoforms differs between liver and oxidative muscle. Importantly, HSP protein levels do not always change concurrently with transcripts, highlighting the importance of measuring both to fully understand the role of HSPs in organismal responses to temperature stress.

Levels of HSPs may increase in response to cold acclimation in stickleback to refold proteins denatured by cold temperature. Similar to heat stress, cold stress weakens non-covalent bonds, destabilizing the tertiary structure of proteins (Adrover et al., 2012). Rates of protein folding also decline with temperature (Scalley and Baker, 1997), which may increase demand for chaperone-mediated protein folding. Hsp $90-\alpha, H s p 60$, and $H s c 70$ transcripts increased in pectoral muscle and $H s p 60$ and $H s c 70$ increased in the liver tissue within the first 2-3 days of cold acclimation in stickleback. HSC70 proteins increased in both liver and pectoral muscle in response to cold acclimation, and HSP90 protein levels tended to increase in liver. Together, these data suggest a greater demand for chaperone-mediated folding as fish adjust to decreases in temperature. Another possibility is that activity of HSPs declines with cold acclimation due to the $\mathrm{Q}_{10}$ effect, and stickleback may simply increase HSP levels to maintain chaperone activity.

Levels of HSPs may also increase during cold acclimation to ameliorate oxidative stress. Levels of oxidatively damaged proteins increased in stickleback livers by week 1 of cold acclimation from $20^{\circ} \mathrm{C}$ to $8{ }^{\circ} \mathrm{C}$ and remained elevated after 4 weeks at $8{ }^{\circ} \mathrm{C}$, but then declined 
and were equivalent to levels in animals at $20^{\circ} \mathrm{C}$ by week 9 (Kammer et al., 2011). Similarly, transcript levels of $H s p 60$ and $H s c 70$ transiently increased during cold acclimation and were highest in animals at $8{ }^{\circ} \mathrm{C}$ (day 3 ) and by week 9 at $8{ }^{\circ} \mathrm{C}$ were equivalent to levels in animals at $20^{\circ} \mathrm{C}$ (start and week 9). HSP90 and HSC70 protein levels were also higher in stickleback livers after 4 weeks at $8^{\circ} \mathrm{C}$ but unlike mRNA levels, HSC70 protein levels remained high. Similar to results from our study, oxidative stress was correlated with $H s p$ expression in hepatocytes of grass carp (Ctenopharyngodon idellus), where lipid peroxidation and hsp70 and hsp $90 \mathrm{mRNA}$ levels increased following exposure to $32^{\circ} \mathrm{C}$ heat stress for $30 \mathrm{~min}$ (Cui et al., 2013).

Increases in oxidative stress in stickleback liver might warrant higher levels of HSPs to assist with folding de novo proteins, preventing protein denaturation, and/or targeting oxidized proteins to the proteasome. Overexpression of HSP60 protects proteins from oxidation in yeast (Saccharomyces cerevisiae) (Cabiscol et al., 2002). It has been proposed that HSP60 binds denatured, iron-centered proteins, preventing the release of free iron, which promotes the production of ROS through the Fenton reaction (Cabiscol et al., 2002). While HSP60 did not increase in stickleback livers in our study, other chaperones may function in a similar fashion. Both HSP90 and HSP70 participate in the ubiquitin-proteasome system for degrading damaged proteins. HSP90 and HSP/HSC70, along with the co-chaperone CHIP, present proteins to the E3 ubiquitin ligase for ubiquitination (Esser et al., 2004). HSP90 also interacts with the proteasome and promotes degradation of oxidatively damaged proteins and prevents inactivation of the proteasome by oxidative stress (Conconi et al., 1998; Whittier et al., 2004). These functions of HSP90 are consistent with its increase in liver where levels of oxidized proteins increase in response to cold acclimation, and its higher level in liver compared to pectoral muscle; levels of 
oxidized proteins and oxidized glutathione are also higher in liver compared to pectoral muscle (Kammer et al., 2011).

The mismatch between transcript levels of $h s p 90-\alpha$ and protein levels of HSP90 in both liver and pectoral muscle may be due to the presence of two isoforms of the protein, HSP90- $\alpha$ and HSP90- $\beta$. We designed primers to quantify transcript levels of HSP90- $\alpha$ because in mammals, HSP90- $\alpha$ is considered to be the inducible isoform, whereas HSP90- $\beta$ is considered the constitutive isoform (Csermely et al., 1998). The antibody we used recognizes both isoforms of the protein. Our data suggests that HSP90- $\beta$, detectable at the protein level, is more highly expressed in liver compared to HSP90- $\alpha$, which we were unable to detect using qRT-PCR. The increase in $h s p 90-\alpha$ mRNA observed in pectoral muscle in response to cold acclimation may have gone undetected at the protein level because of low abundance of this isoform.

Increases in HSC70 in the pectoral adductor muscle and liver may facilitate mitochondrial biogenesis and import of nuclear-encoded proteins into mitochondria. While mitochondrial biogenesis occurs in pectoral muscle but not liver in response to cold acclimation, the activity of enzymes located within the mitochondrion increase in both pectoral muscle and liver (Orczewska et al., 2010). Activity of citrate synthase (CS), reflecting protein levels, increased in liver by week 1 of cold acclimation to $8{ }^{\circ} \mathrm{C}$ and in pectoral muscle by week 9 (Orczewska et al., 2010). Cytochrome c oxidase (COX) activity increased by day 2 of cold acclimation in pectoral muscle but not until week 9 in liver (Orczewska et al., 2010). HSC70 protein levels increased by week 4 of acclimation to $8{ }^{\circ} \mathrm{C}$ in both liver and pectoral adductor muscle but may have increased prior to this; we did not measure protein levels prior to week 4 . Transcript levels of $h s c 70$ significantly increased by day 2 of cold acclimation $\left(10^{\circ} \mathrm{C}\right)$ in both 
tissues, suggesting protein levels may have increased earlier than week 4 to assist with protein import to the mitochondrion.

HSP60 was abundant in both liver and pectoral muscle and while mRNA levels of $h s p 60$ increased in both tissues in response to cold acclimation, protein levels remained unchanged. HSP60 is a chaperonin that provides an enclosed barrel-like structure for protein folding (Saibil, 2013). It is localized to both the mitochondrion and cytosol where it folds de novo proteins and ones denatured by stress (Saibil, 2013). The discordance between HSP60 transcript abundance and protein levels suggests post-transcriptional regulation of protein levels. Additionally, the increase in $h s p 60$ mRNA levels may be due to a decrease in decay rate, rather than gene induction, as shown for COX and housekeeping genes in cold-acclimated goldfish (Bremer and Moyes, 2014).

While transcript levels of the putative constitutive isoform of HSP70, hsc70, increased in response to cold acclimation, $h s p 70$ was not consistently detected in either pectoral muscle or livers of stickleback. Protein levels of HSP70 may have been undetectable because we used an antibody raised against the C-terminus of the protein in salmon, a region that is not well conserved (supplemental material Fig. S3). The lack of increase in $h s p 70$ suggests that HSP70, well-known to be induced by heat stress, may not be as strongly induced by cold stress, while hsc70 may be induced by both increases and decreases in temperature. Consistent with this, levels of hsc70 mRNA significantly increased in muscle of the common carp (Cyprinus carpio) in response to heat stress $\left(26^{\circ} \mathrm{C}\right)$ and cold stress $\left(5^{\circ} \mathrm{C}\right)$ for $1-5 \mathrm{~h}$, while $h s p 70 \mathrm{mRNA}$ did not change in skin or spleen with cold stress (Ali et al., 2003; Ferencz et al., 2012).

SIRTs have been shown to regulate the expression of HSPs (Westerheide et al., 2009). In mammals, acetylation of K80 within HSF1 attenuates the heat-shock response by reducing DNA 
binding of HSF1 to the heat-shock element (HSE) (Westerheide et al., 2009). Deacetylation by SIRT1 enhances HSF1 binding to HSE and maintains high levels of expression of HSP70 (Westerheide et al., 2009). The kinetics of induction of sirt1 and sirt2 in liver were similar to the induction of $h s p 60$ and $h s c 70$ in stickleback (this study, Orczewska et al., 2010). Thus, the increase in sirtl in liver, where oxidative stress occurs during cold acclimation, may drive increases in HSPs to refold oxidatively damaged proteins.

SIRT1 may also mediate adjustments in metabolism that occur during cold acclimation of stickleback. (Imai et al., 2000; Landry et al., 2000). Increases in NAD ${ }^{+}$, indicative of a low energy charge, increase activity of SIRT1 and SIRT2 (Canto et al., 2009; Wang et al., 2007) and activity of SIRT1 is correlated with CS activity (Gurd et al., 2011). In our study, we did not measure SIRT protein levels but both sirtl and sirt2 mRNA levels increased in liver and sirt1 increased in pectoral muscle during cold acclimation. In liver, mRNA levels of sirtl increased on day 2 of cold acclimation $\left(10^{\circ} \mathrm{C}\right)$, coinciding with an increase in CS mRNA and preceding an increase in CS activity that occurs at week 1 of cold acclimation (this study and Orczewska et al., 2010). Similarly, increases in sirt $1 \mathrm{mRNA}$ in pectoral muscle on day $3\left(8^{\circ} \mathrm{C}\right)$ precede increases in CS mRNA levels at 1 week of cold acclimation and CS activity at week 9 of cold acclimation, suggesting SIRT1 may enhance aerobic metabolic capacity during cold acclimation of stickleback (this study and Orczewska et al., 2010).

In pectoral adductor muscle, SIRT1 may also activate mitochondrial biogenesis. In mammals, SIRT1 stimulates mitochondrial biogenesis by deacetylating and activating peroxisome proliferator-activated receptor- $\gamma$ coactivator-1 alpha (PGC-1 $\alpha$ ), considered the master regulator of mitochondrial biogenesis in mammals (Lehman et al., 2000). In fish, the NRF-1 binding domain of $P G C$ - $1 \alpha$ is not conserved, likely impeding its ability to induce 
mitochondrial biogenesis (LeMoine et al., 2010). This may explain why mRNA levels of $P G C$ $1 \alpha$ do not increase in response to cold acclimation or exercise in muscle of goldfish or stickleback despite increases in aerobic metabolic capacity (Bremer et al., 2012; LeMoine et al., 2008; Orczewska et al., 2010). Although NRF-1, rather than PGC-1 $\alpha$, appears to mediate mitochondrial biogenesis in fish, SIRTs1 may play a similar role, deacylating and activating NRF-1.

Sirtuins also activate pathways that alleviate oxidative stress. In response to ROS in mammals, Sirt2 deacetylates the forkhead transcription factor FoxO, which induces expression of sod2 (Kops et al., 2002; Wang et al., 2007). Sirt1 also increases expression of sod2 through FoxO transcription factors (Tanno et al., 2010) and PGC-1 $\alpha$, which induces expression of sod2 and CAT (Aquilano et al., 2013; Geng et al., 2011; Rodgers et al., 2005). Activity of SOD increases by day $2\left(10^{\circ} \mathrm{C}\right)$ in the pectoral muscle and day $3\left(8^{\circ} \mathrm{C}\right)$ in the liver of stickleback, which coincides with increases in sirt1 mRNA, although SOD transcripts did not increase in response to cold acclimation in either tissue (Kammer et al., 2011).

Both SIRT3 and SIRT4 regulate metabolism, however, neither increased in response to cold acclimation in liver or pectoral muscle. PGC-1 $\alpha$ drives increases in mRNA and protein expression of Sirt3 (Kong et al., 2010). Given that there is no increase in $P G C$ - $1 \alpha$ mRNA in either liver or muscle during cold acclimation of threespine stickleback (Orczewska et al., 2010), it is not surprising that we did not find an increase in sirt3 mRNA.

\section{Conclusions}

During cold acclimation of threespine stickleback, there are tissue- and isoform-specific changes in $h s p$ and sirt mRNA, which may reflect differences in metabolic remodeling and/or 
oxidative stress between the two tissues. Thus, HSPs are not only essential for enhancing survival during periods of acute changes in temperature, but also for adjusting to moderate decreases in temperature during cold acclimation. Sirtuins may play a role in regulating levels of HSPs and/or changes in metabolism during cold acclimation; further studies are warranted to verify this. The lack of correlation between changes in HSP transcript and protein levels highlights the importance of cautiously interpreting the physiological implications of changes in HSP transcript levels.

\section{Acknowledgements}

This research was supported by a National Science Foundation grant to K.M.O. (IOS-0643857).

\section{References}

Adrover, M., Martorell, G., Martin, S.R., Urosev, D., Konarev, P.V., Svergun, D.I., Daura, X., Temussi, P., Pastore, A., 2012. The role of hydration in protein stability: comparison of the cold and heat unfolded states of Yfh1. J. Mol. Biol. 417, 413-424.

Ahn, B.H., Kim, H.S., Song, S., Lee, I.H., Liu, J., Vassilopoulos, A., Deng, C.X., Finkel, T., 2008. A role for the mitochondrial deacetylase Sirt3 in regulating energy homeostasis. Proc.

Natl. Acad. Sci. U.S.A. 105, 14447-14452.

Ali, K.S., Dorgai, L., Abraham, M., Hermesz, E., 2003. Tissue- and stressor-specific differential expression of two hsc70 genes in carp. Biochem. Biophys. Res. Commun. 307, 503-509.

Aquilano, K., Baldelli, S., Pagliei, B., Cannata, S.M., Rotilio, G., Ciriolo, M.R., 2013. p53 orchestrates the PGC-1alpha-mediated antioxidant response upon mild redox and metabolic imbalance. Antioxid. Redox Signal. 18, 386-399.

Baker, M., Tatsuta, T., Langer, T., 2012. Quality control of mitochondrial proteostasis, in: R.I. Morimoto, D. Selkoe, J. Kelly (Eds.), Protein Homeostasis. Cold Spring Harbor Laboratory Press, New York, 161-179.

Bradford, M.M., 1976. A rapid and sensitive method for the quantitation of microgram quantities of protein utilizing the principle of protein-dye binding. Analytical biochemistry 72, 248-254. Bremer, K., Monk, C.T., Gurd, B.J., Moyes, C.D., 2012. Transcriptional regulation of temperature-induced remodeling of muscle bioenergetics in goldfish. Am. J. Physiol. Regul. Integr. Comp. Physiol. 303, R150-158.

Bremer, K., Moyes, C.D., 2014. mRNA degradation: an underestimated factor in steady-state transcript levels of cytochrome c oxidase subunits? The Journal of experimental biology 217, 2212-2220. 
Brenmoehl, J., Hoeflich, A., 2013. Dual control of mitochondrial biogenesis by sirtuin 1 and sirtuin 3. Mitochondrion 13, 755-761.

Cabiscol, E., Belli, G., Tamarit, J., Echave, P., Herrero, E., Ros, J., 2002. Mitochondrial Hsp60, resistance to oxidative stress, and the labile iron pool are closely connected in Saccharomyces cerevisiae. J. Biol. Chem. 277, 44531-44538.

Canto, C., Gerhart-Hines, Z., Feige, J.N., Lagouge, M., Noriega, L., Milne, J.C., Elliott, P.J., Puigserver, P., Auwerx, J., 2009. AMPK regulates energy expenditure by modulating NAD+ metabolism and SIRT1 activity. Nature 458, 1056-1060.

Cheng, M.Y., Hartl, F.U., Martin, J., Pollock, R.A., Kalousek, F., Neupert, W., Hallberg, E.M., Hallberg, R.L., Horwich, A.L., 1989. Mitochondrial heat-shock protein hsp60 is essential for assembly of proteins imported into yeast mitochondria. Nature 337, 620-625.

Clark, M.S., Fraser, K.P.P., Burns, G., Peck, L.S., 2008. The HSP70 heat shock response in the Antarctic fish Harpagifer antarcticus. Polar Biol. 31, 171-180.

Conconi, M., Petropoulos, I., Emod, I., Turlin, E., Biville, F., Friguet, B., 1998. Protection from oxidative inactivation of the $20 \mathrm{~S}$ proteasome by heat-shock protein 90 . The Biochemical journal 333 ( Pt 2), 407-415.

Craig, E.A., Kramer, J., Shilling, J., Werner-Washburne, M., Holmes, S., Kosic-Smithers, J., Nicolet, C.M., 1989. SSC1, an essential member of the yeast HSP70 multigene family, encodes a mitochondrial protein. Mol. Cell Biol. 9, 3000-3008.

Csermely, P., Schnaider, T., Soti, C., Prohaszka, Z., Nardai, G., 1998. The 90-kDa molecular chaperone family: structure, function, and clinical applications. A comprehensive review.

Pharmacology \& therapeutics 79, 129-168.

Cui, Y., Liu, B., Xie, J., Xu, P., Habte-Tsion, H.M., Zhang, Y., 2013. Effect of heat stress and recovery on viability, oxidative damage, and heat shock protein expression in hepatic cells of grass carp (Ctenopharyngodon idellus). Fish Physiol. Biochem.

Dietz, T.J., Somero, G.N., 1992. The threshold induction temperature of the 90-kDa heat shock protein is subject to acclimatization in eurythermal goby fishes (genus Gillichthys). Proceedings of the National Academy of Sciences of the United States of America 89, 3389-3393.

Donaldson, M.R., Cooke, S.J., Patterson, D.A., Macdonald, J.S., 2008. Cold shock and fish. J Fish Biol 73, 1491-1530.

Egginton, S., Sidell, B.D., 1989. Thermal acclimation induces adaptive changes in subcellular structure of fish skeletal muscle. Am. J. Physiol. 256, R1-9.

Elliott, J.M., Elliott, J.A., 2010. Temperature requirements of Atlantic salmon Salmo salar, brown trout Salmo trutta and Arctic charr Salvelinus alpinus: predicting the effects of climate change. J. Fish. Biol. 77, 1793-1817.

Esser, C., Alberti, S., Hohfeld, J., 2004. Cooperation of molecular chaperones with the ubiquitin/proteasome system. Biochimica et biophysica acta 1695, 171-188.

Fangue, N.A., Richards, J.G., Schulte, P.M., 2009. Do mitochondrial properties explain intraspecific variation in thermal tolerance? J. Exp. Biol. 212, 514-522.

Feder, M.E., Hofmann, G.E., 1999. Heat-shock proteins, molecular chaperones, and the stress response: evolutionary and ecological physiology. Annu. Rev. Physiol. 61, 243-282.

Ferencz, A., Juhasz, R., Butnariu, M., Deer, A.K., Varga, I.S., Nemcsok, J., 2012. Expression analysis of heat shock genes in the skin, spleen and blood of common carp (Cyprinus carpio) after cadmium exposure and hypothermia. Acta Biol. Hung. 63, 15-25. 
Finley, L.W., Haas, W., Desquiret-Dumas, V., Wallace, D.C., Procaccio, V., Gygi, S.P., Haigis, M.C., 2011. Succinate dehydrogenase is a direct target of sirtuin 3 deacetylase activity. PloS one 6, e23295.

Gambini, J., Gomez-Cabrera, M.C., Borras, C., Valles, S.L., Lopez-Grueso, R., Martinez-Bello, V.E., Herranz, D., Pallardo, F.V., Tresguerres, J.A., Serrano, M., Vina, J., 2011. Free $[\mathrm{NADH}] /[\mathrm{NAD}(+)]$ regulates sirtuin expression. Arch. Biochem. Biophys. 512, 24-29.

Geng, T., Li, P., Yin, X., Yan, Z., 2011. PGC-1alpha promotes nitric oxide antioxidant defenses and inhibits FOXO signaling against cardiac cachexia in mice. Am. J. Pathol. 178, 1738-1748. Gurd, B.J., Yoshida, Y., McFarlan, J.T., Holloway, G.P., Moyes, C.D., Heigenhauser, G.J., Spriet, L., Bonen, A., 2011. Nuclear SIRT1 activity, but not protein content, regulates mitochondrial biogenesis in rat and human skeletal muscle. Am. J. Physiol. Regul. Integr. Comp. Physiol. 301, R67-75.

Han, G.D., Zhang, S., Marshall, D.J., Ke, C.H., Dong, Y.W., 2013. Metabolic energy sensors (AMPK and SIRT1), protein carbonylation and cardiac failure as biomarkers of thermal stress in an intertidal limpet: linking energetic allocation with environmental temperature during aerial emersion. J. Exp. Biol. 216, 3273-3282.

Hartl, F.U., 1996. Molecular chaperones in cellular protein folding. Nature 381, 571-579. Heise, K., Estevez, M.S., Puntarulo, S., Galleano, M., Nikinmaa, M., Portner, H.O., Abele, D., 2007. Effects of seasonal and latitudinal cold on oxidative stress parameters and activation of hypoxia inducible factor (HIF-1) in zoarcid fish. J. Comp. Physiol. B 177, 765-777.

Hirschey, M.D., Shimazu, T., Goetzman, E., Jing, E., Schwer, B., Lombard, D.B., Grueter, C.A., Harris, C., Biddinger, S., Ilkayeva, O.R., Stevens, R.D., Li, Y., Saha, A.K., Ruderman, N.B., Bain, J.R., Newgard, C.B., Farese, R.V., Jr., Alt, F.W., Kahn, C.R., Verdin, E., 2010. SIRT3 regulates mitochondrial fatty-acid oxidation by reversible enzyme deacetylation. Nature 464, 121-125.

Hochachka, P., Somero, G.N., 2002. Biochemical Adaptation: Mechanism and Process in Physiological Evolution. Oxford University Press, Oxford.

Hori, Y.S., Kuno, A., Hosoda, R., Horio, Y., 2013. Regulation of FOXOs and p53 by SIRT1 modulators under oxidative stress. PloS one 8, e73875.

Ibarz, A., Martin-Perez, M., Blasco, J., Bellido, D., de Oliveira, E., Fernandez-Borras, J., 2010. Gilthead sea bream liver proteome altered at low temperatures by oxidative stress. Proteomics 10, 963-975.

Imai, S., Armstrong, C.M., Kaeberlein, M., Guarente, L., 2000. Transcriptional silencing and longevity protein Sir2 is an NAD-dependent histone deacetylase. Nature 403, 795-800.

Janska, A., Aprile, A., Zamecnik, J., Cattivelli, L., Ovesna, J., 2011. Transcriptional responses of winter barley to cold indicate nucleosome remodelling as a specific feature of crown tissues.

Funct. Integr. Genomics 11, 307-325.

Johnston, I.A., Maitland, B., 1980. Temperature acclimation in crucian carp, Carassius carassius L., morphometric analyses of muscle fibre ultrastructure. J. Fish Biol. 17, 113-125.

Kammer, A.R., Orczewska, J.I., O'Brien, K.M., 2011. Oxidative stress is transient and tissue specific during cold acclimation of threespine stickleback. J. Exp. Biol. 214, 1248-1256.

Kang, P.J., Ostermann, J., Shilling, J., Neupert, W., Craig, E.A., Pfanner, N., 1990. Requirement for hsp70 in the mitochondrial matrix for translocation and folding of precursor proteins. Nature 348, 137-143.

Kim, Y.E., Hipp, M.S., Bracher, A., Hayer-Hartl, M., Hartl, F.U., 2013. Molecular chaperone functions in protein folding and proteostasis. Annual review of biochemistry 82, 323-355. 
Kong, X., Wang, R., Xue, Y., Liu, X., Zhang, H., Chen, Y., Fang, F., Chang, Y., 2010. Sirtuin 3, a new target of PGC-1alpha, plays an important role in the suppression of ROS and mitochondrial biogenesis. PloS one 5, e11707.

Kops, G.J., Dansen, T.B., Polderman, P.E., Saarloos, I., Wirtz, K.W., Coffer, P.J., Huang, T.T., Bos, J.L., Medema, R.H., Burgering, B.M., 2002. Forkhead transcription factor FOXO3a protects quiescent cells from oxidative stress. Nature 419, 316-321.

Lamarre, S.G., Le Francois, N.R., Driedzic, W.R., Blier, P.U., 2009. Protein synthesis is lowered while $20 \mathrm{~S}$ proteasome activity is maintained following acclimation to low temperature in juvenile spotted wolffish (Anarhichas minor Olafsen). J. Exp. Biol. 212, 1294-1301.

Landry, J., Sutton, A., Tafrov, S.T., Heller, R.C., Stebbins, J., Pillus, L., Sternglanz, R., 2000. The silencing protein SIR2 and its homologs are NAD-dependent protein deacetylases. Proc.

Natl. Acad. Sci. U. S. A. 97, 5807-5811.

Lehman, J.J., Barger, P.M., Kovacs, A., Saffitz, J.E., Medeiros, D.M., Kelly, D.P., 2000.

Peroxisome proliferator-activated receptor gamma coactivator-1 promotes cardiac mitochondrial biogenesis. J. Clin. Invest. 106, 847-856.

LeMoine, C.M., Genge, C.E., Moyes, C.D., 2008. Role of the PGC-1 family in the metabolic adaptation of goldfish to diet and temperature. J. Exp. Biol. 211, 1448-1455.

LeMoine, C.M., Lougheed, S.C., Moyes, C.D., 2010. Modular evolution of PGC-1alpha in vertebrates. J. Mol. Evol. 70, 492-505.

Lindquist, S., 1986. The heat-shock response. Annu. Rev. Biochem. 55, 1151-1191.

Lithgow, T., Ryan, M., Anderson, R.L., Hoj, P.B., Hoogenraad, N.J., 1993. A constitutive form

of heat-shock protein 70 is located in the outer membranes of mitochondria from rat liver. FEBS Lett. 332, 277-281.

Lopez-Matas, M.A., Nunez, P., Soto, A., Allona, I., Casado, R., Collada, C., Guevara, M.A., Aragoncillo, C., Gomez, L., 2004. Protein cryoprotective activity of a cytosolic small heat shock protein that accumulates constitutively in chestnut stems and is up-regulated by low and high temperatures. Plant Physiol. 134, 1708-1717.

Lotz, C., Lin, A.J., Black, C.M., Zhang, J., Lau, E., Deng, N., Wang, Y., Zong, N.C., Choi, J.H., $\mathrm{Xu}$, T., Liem, D.A., Korge, P., Weiss, J.N., Hermjakob, H., Yates, J.R., Apweiler, R., Ping, P., 2013. The Characterization, Design, and Function of the Mitochondrial Proteome: From Organs to Organisms. J. Proteome Res.

Michishita, E., Park, J.Y., Burneskis, J.M., Barrett, J.C., Horikawa, I., 2005. Evolutionarily conserved and nonconserved cellular localizations and functions of human SIRT proteins.

Molecular biology of the cell 16, 4623-4635.

Mogk, A., Bukau, B., Deuerling, E., 2001. Cellular functions of cytosolic E. coli chaperones, in: P. Lund (Ed.), Molecular Chaperones in the Cell. Oxford University Press, New York, 1-34.

Nathan, D.F., Vos, M.H., Lindquist, S., 1997. In vivo functions of the Saccharomyces cerevisiae Hsp90 chaperone. Proceedings of the National Academy of Sciences of the United States of America 94, 12949-12956.

Nelson, R.J., Ziegelhoffer, T., Nicolet, C., Werner-Washburne, M., Craig, E.A., 1992. The translation machinery and $70 \mathrm{kd}$ heat shock protein cooperate in protein synthesis. Cell 71, 97105.

Orczewska, J.I., Hartleben, G., O'Brien, K.M., 2010. The molecular basis of aerobic metabolic remodeling differs between oxidative muscle and liver of threespine sticklebacks in response to cold acclimation. Am. J. Physiol. Regul. Integr. Comp. Physiol. 299, R352-364. 
Osborne, B., Cooney, G.J., Turner, N., 2013. Are sirtuin deacylase enzymes important modulators of mitochondrial energy metabolism? Biochim. Biophys. Acta.

Place, S.P., Zippay, M.L., Hofmann, G.E., 2004. Constitutive roles for inducible genes: evidence for the alteration in expression of the inducible hsp70 gene in Antarctic notothenioid fishes. Am. J. Physiol. Regul. Integr. Comp. Physiol. 287, R429-436.

Podrabsky, J.E., Somero, G.N., 2004. Changes in gene expression associated with acclimation to constant temperatures and fluctuating daily temperatures in an annual killifish Austrofundulus limnaeus. The Journal of experimental biology 207, 2237-2254.

Qiu, X., Brown, K., Hirschey, M.D., Verdin, E., Chen, D., 2010. Calorie restriction reduces oxidative stress by SIRT3-mediated SOD2 activation. Cell Metab. 12, 662-667.

Rinehart, J.P., Hayward, S.A., Elnitsky, M.A., Sandro, L.H., Lee, R.E., Jr., Denlinger, D.L., 2006. Continuous up-regulation of heat shock proteins in larvae, but not adults, of a polar insect. Proc. Natl. Acad. Sci. U. S. A. 103, 14223-14227.

Rinehart, J.P., Li, A., Yocum, G.D., Robich, R.M., Hayward, S.A., Denlinger, D.L., 2007. Upregulation of heat shock proteins is essential for cold survival during insect diapause. Proc. Natl. Acad. Sci. U. S. A. 104, 11130-11137.

Rodgers, J.T., Lerin, C., Haas, W., Gygi, S.P., Spiegelman, B.M., Puigserver, P., 2005. Nutrient control of glucose homeostasis through a complex of PGC-1alpha and SIRT1. Nature 434, 113118.

Saibil, H., 2013. Chaperone machines for protein folding, unfolding and disaggregation. Nature reviews. Molecular cell biology 14, 630-642.

Scalley, M.L., Baker, D., 1997. Protein folding kinetics exhibit an Arrhenius temperature dependence when corrected for the temperature dependence of protein stability. Proc. Natl. Acad. Sci. U.S.A. 94, 10636-10640.

Schwer, B., Bunkenborg, J., Verdin, R.O., Andersen, J.S., Verdin, E., 2006. Reversible lysine acetylation controls the activity of the mitochondrial enzyme acetyl-CoA synthetase 2. Proc. Natl. Acad. Sci. U.S.A. 103, 10224-10229.

Tanno, M., Kuno, A., Yano, T., Miura, T., Hisahara, S., Ishikawa, S., Shimamoto, K., Horio, Y., 2010. Induction of manganese superoxide dismutase by nuclear translocation and activation of SIRT1 promotes cell survival in chronic heart failure. J. Biol. Chem. 285, 8375-8382.

Taylor, S.W., Fahy, E., Zhang, B., Glenn, G.M., Warnock, D.E., Wiley, S., Murphy, A.N., Gaucher, S.P., Capaldi, R.A., Gibson, B.W., Ghosh, S.S., 2003. Characterization of the human heart mitochondrial proteome. Nat. Biotechnol. 21, 281-286.

Todgham, A.E., Hoaglund, E.A., Hofmann, G.E., 2007. Is cold the new hot? Elevated ubiquitinconjugated protein levels in tissues of Antarctic fish as evidence for cold-denaturation of proteins in vivo. J. Comp. Physiol. B 177, 857-866.

Todgham, A.E., Schulte, P.M., Iwama, G.K., 2005. Cross-tolerance in the tidepool sculpin: the role of heat shock proteins. Physiological and biochemical zoology : PBZ 78, 133-144.

Tomanek, L., Somero, G.N., 1999. Evolutionary and acclimation-induced variation in the heatshock responses of congeneric marine snails (genus Tegula) from different thermal habitats: implications for limits of thermotolerance and biogeography. The Journal of experimental biology 202, 2925-2936.

Tseng, Y.C., Chen, R.D., Lucassen, M., Schmidt, M.M., Dringen, R., Abele, D., Hwang, P.P., 2011. Exploring uncoupling proteins and antioxidant mechanisms under acute cold exposure in brains of fish. PloS one 6, e18180. 
Wang, F., Nguyen, M., Qin, F.X., Tong, Q., 2007. SIRT2 deacetylates FOXO3a in response to oxidative stress and caloric restriction. Aging Cell 6, 505-514.

Westerheide, S.D., Anckar, J., Stevens, S.M., Jr., Sistonen, L., Morimoto, R.I., 2009. Stressinducible regulation of heat shock factor 1 by the deacetylase SIRT1. Science (New York, N.Y.) 323, 1063-1066.

Whittier, J.E., Xiong, Y., Rechsteiner, M.C., Squier, T.C., 2004. Hsp90 enhances degradation of oxidized calmodulin by the $20 \mathrm{~S}$ proteasome. The Journal of biological chemistry 279, 4613546142.

Young, J.C., Hoogenraad, N.J., Hartl, F.U., 2003. Molecular Chaperones Hsp90 and Hsp70 Deliver Preproteins to the Mitochondrial Import Receptor Tom70. Cell 112, 41-50.

\section{Figure legends}

Fig. 1. HSP mRNA transcript levels in liver (A \& C) and pectoral adductor muscle (B \& D) of threespine stickleback during cold acclimation. Transcript levels of HSPs were normalized to transcript levels of the housekeeping gene $E F-1 \alpha$ in pectoral muscle and $18 S$ in liver. Significant differences are indicated by different letters $(P<0.05)$. Values are mean \pm SEM, $N=5-9$.

Fig. 2. Levels of HSP protein in liver $(B \& E)$ and pectoral adductor muscle $(C \& F)$ of threespine stickleback during cold acclimation. Representative western blots of HSP 60 (A), HSP 90 (A) and HSC 70 (D) in liver (lanes 1-4) and pectoral adductor muscle (lanes 5-8). Lanes 1 and $5,20{ }^{\circ} \mathrm{C}$; lanes 2 and $6,8{ }^{\circ} \mathrm{C}$ week 4 ; lanes 3 and $7,8{ }^{\circ} \mathrm{C}$ week 9 ; lanes 4 and 8, $20{ }^{\circ} \mathrm{C}$ week 9. Protein levels were standardized to levels in animals at $20^{\circ} \mathrm{C}$ for each HSP in each tissue. Significant differences are indicated by different letters $(P<0.05$, except for HSC70 in pectoral muscle in which $P<0.10$ ). Values are mean $\pm \mathrm{SEM}, \mathrm{N}=4-6$.

Fig. 3 SIRT mRNA transcript levels in liver (A \& C) and pectoral adductor muscle (B \& D) of threespine stickleback during cold acclimation. Transcript levels of SIRTs were normalized to transcript levels of the housekeeping gene $E F-1 \alpha$ in pectoral muscle and $18 S$ in liver. Significant differences are indicated by different letters $(P<0.05)$. Values are mean \pm SEM, N $=3-11$. 
Figure 1

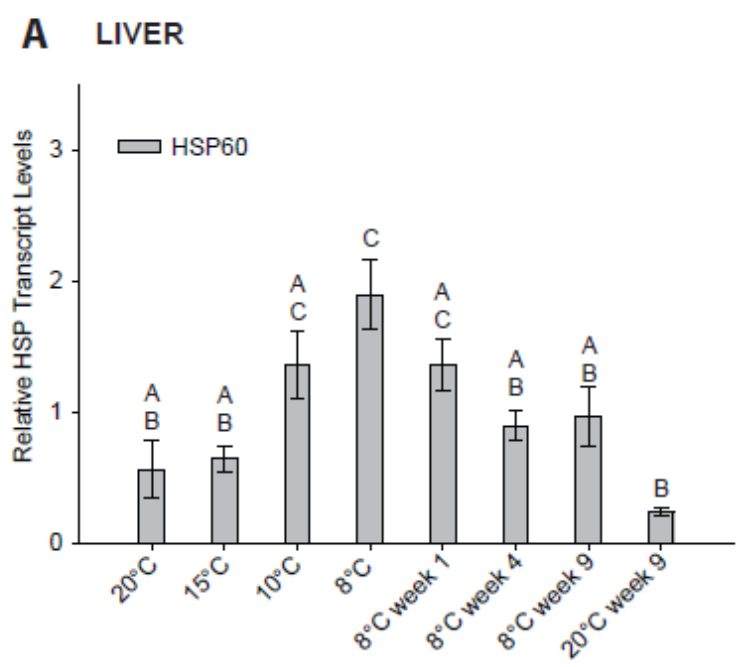

\section{B PECTORAL MUSCle}

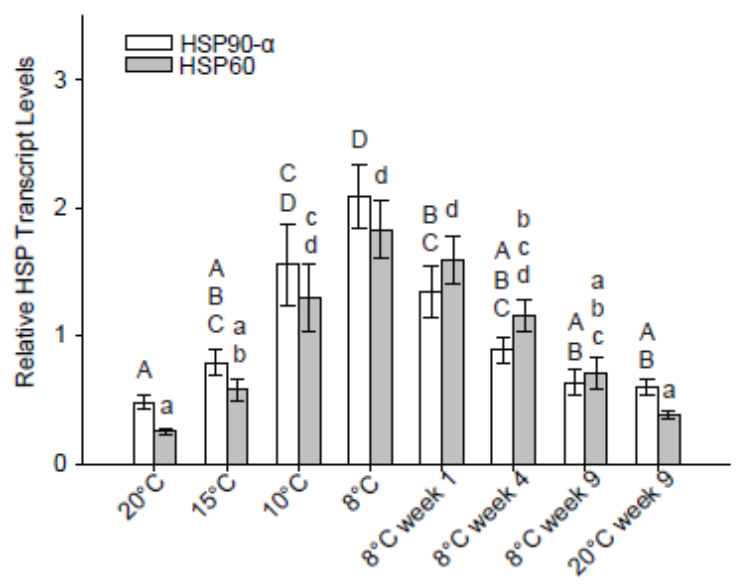

C LIVER

D PECTORAL MUSCLE
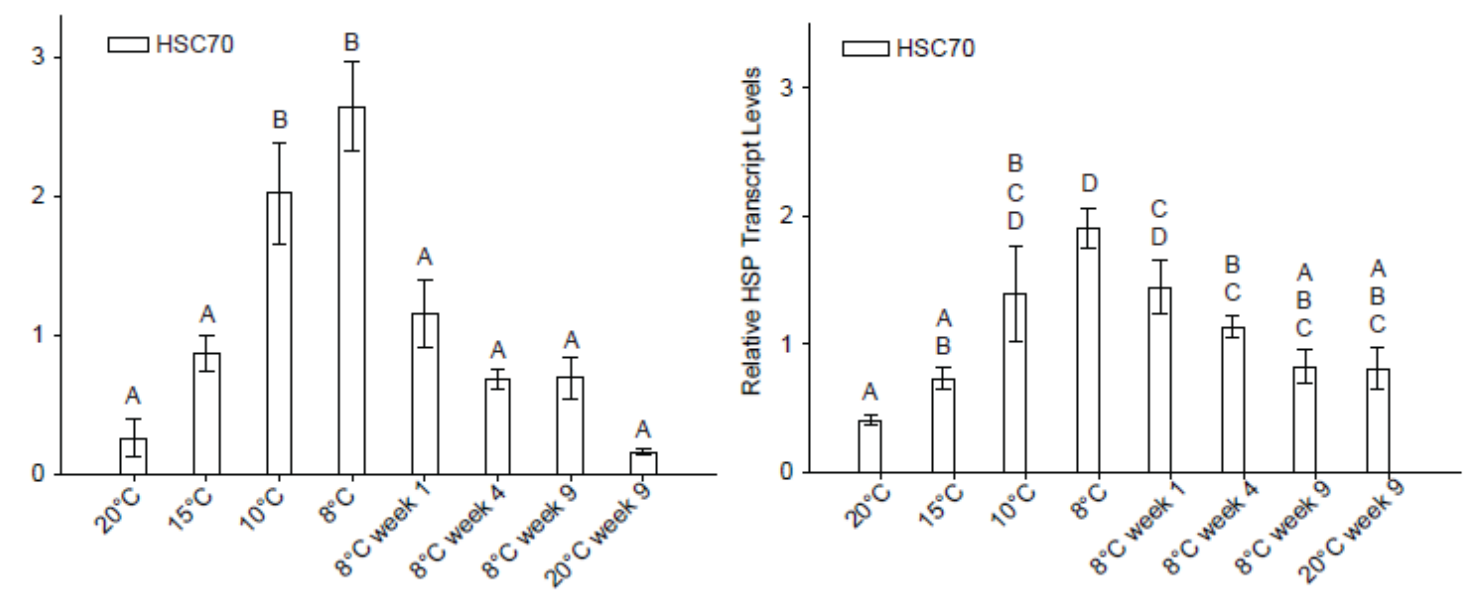
Figure 2
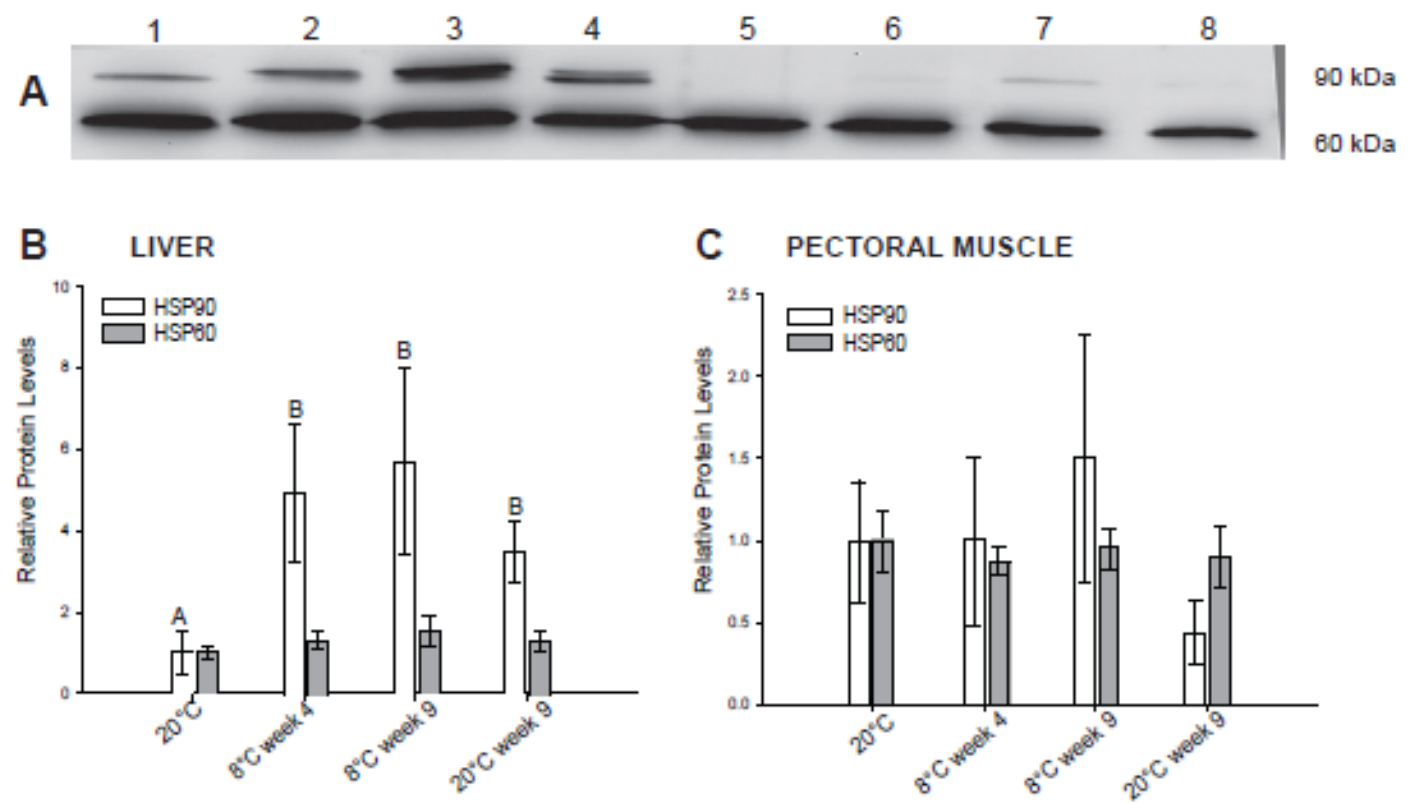

C PECTORAL MUSClE
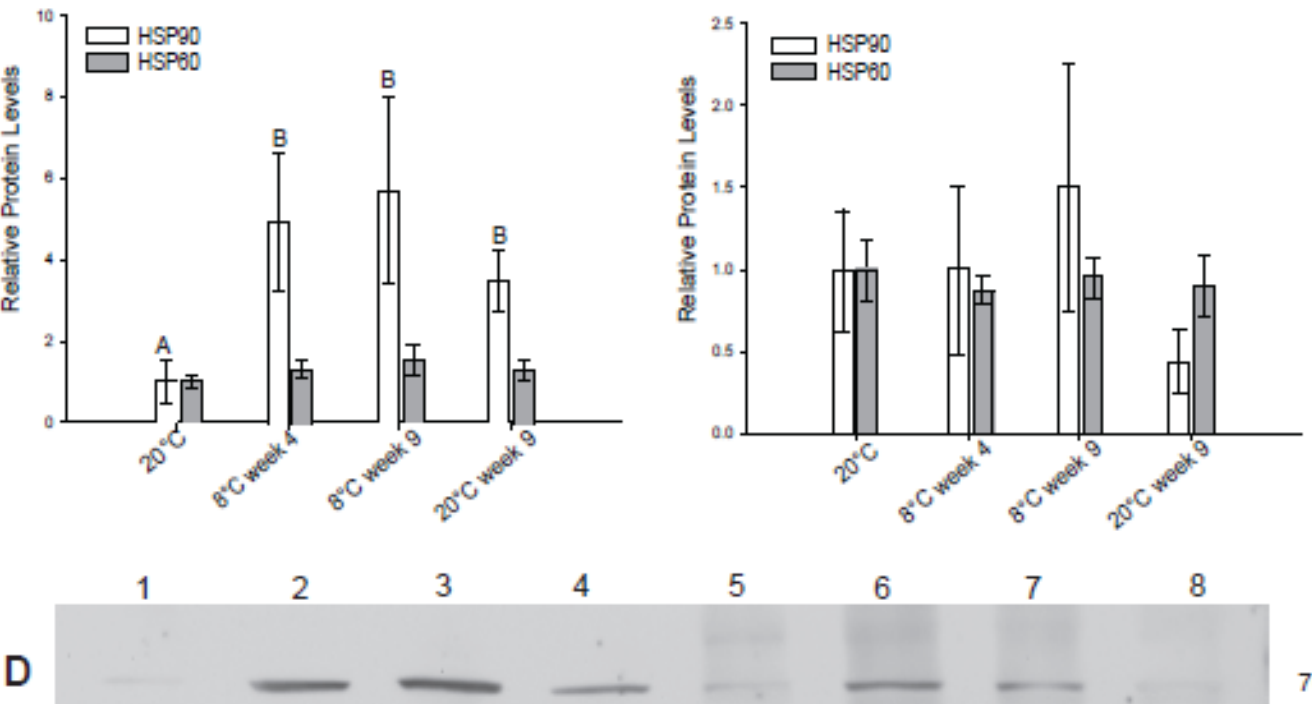

D 5 6 7 8
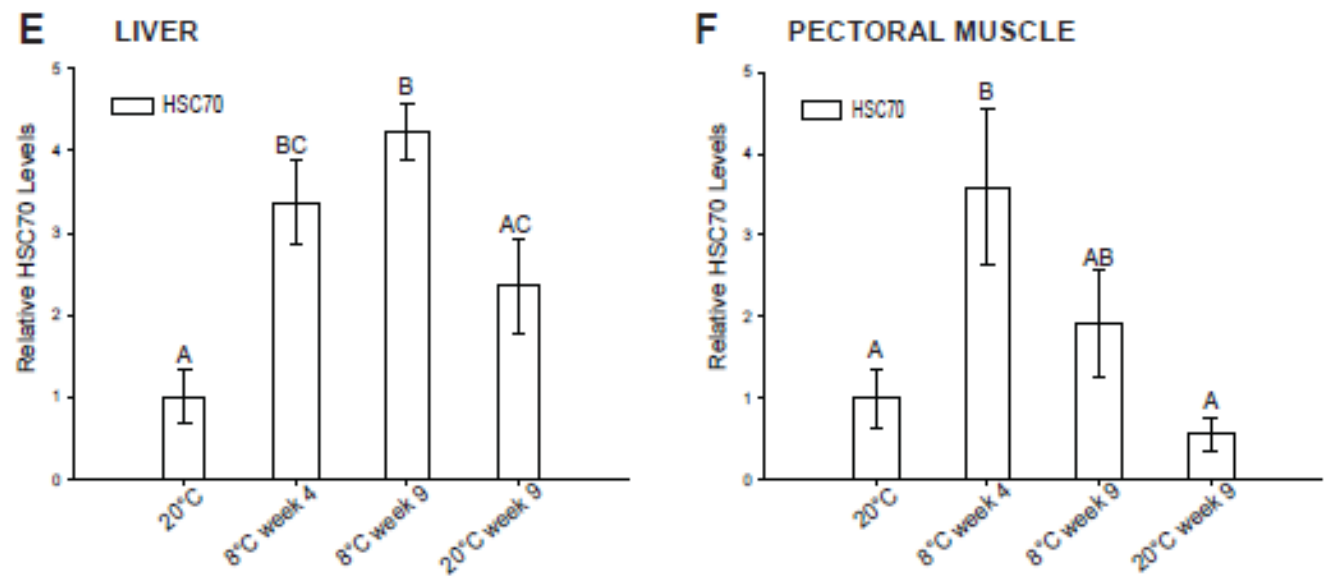
Figure 3
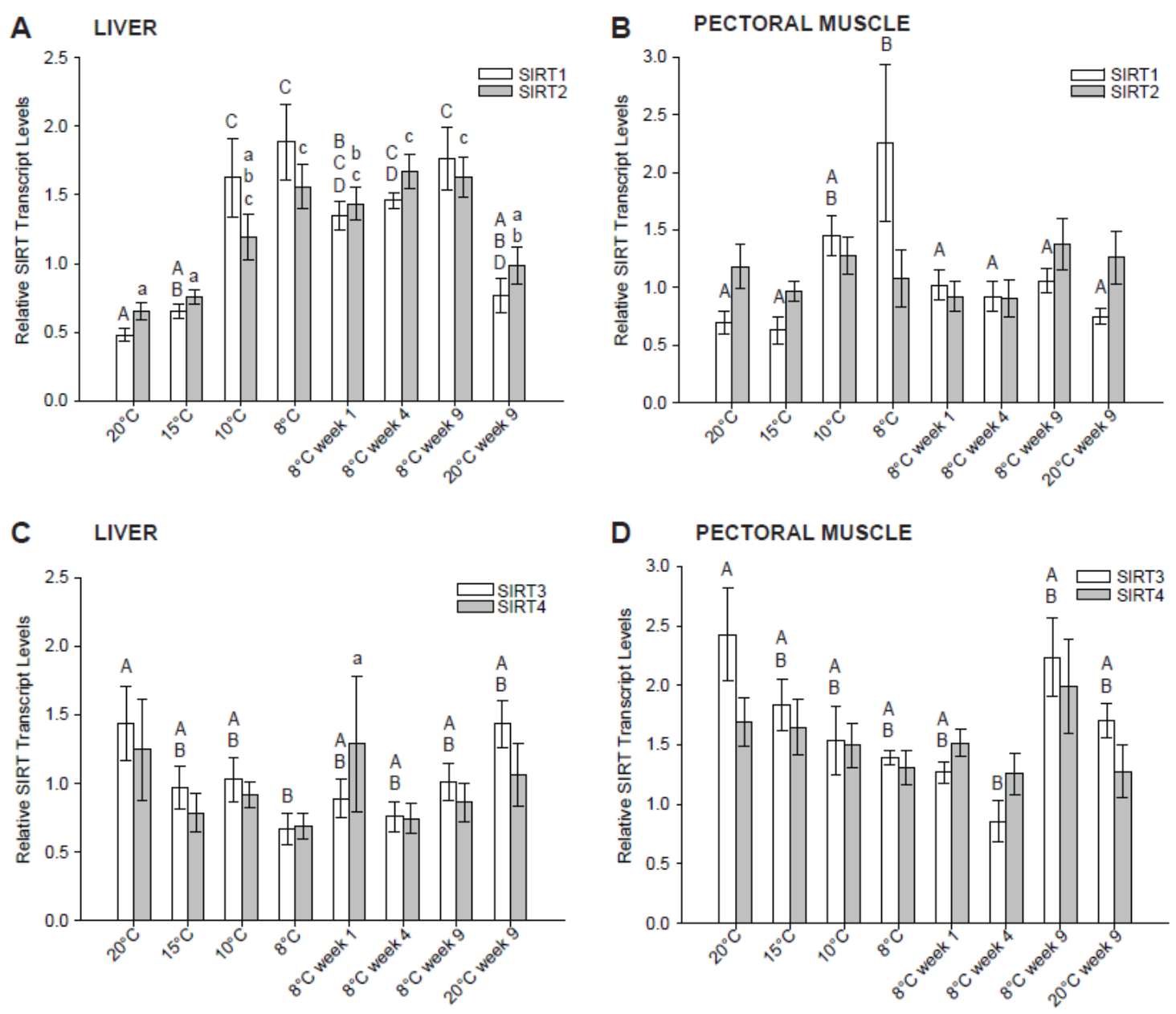
Table 1. Primers used for quantitative real-time PCR.

\begin{tabular}{|c|c|c|c|c|c|}
\hline $\begin{array}{l}\text { Gene (Ensembl ID } \\
\text { ENSGACT000000) }\end{array}$ & Forward Primer & Reverse Primer & $\begin{array}{l}\text { Amplicon } \\
\text { (bp) }\end{array}$ & $\begin{array}{l}\text { Efficiency } \\
\text { in pectoral } \\
\text { muscle }\end{array}$ & $\begin{array}{l}\text { Efficiency } \\
\text { in liver }\end{array}$ \\
\hline $18 \mathrm{~S}(21793)$ & $\begin{array}{l}\text { 5'ACCACATCCAAG } \\
\text { GAAGGCAG3' }\end{array}$ & $\begin{array}{l}\text { 5'CCGAGTCGGGAG } \\
\text { TGGGTAAT3' }\end{array}$ & 51 & N/A & 1.62 \\
\hline $\mathrm{EF}-1 \alpha(02143)$ & $\begin{array}{l}\text { 5'CGTCTACAAAAT } \\
\text { CGGAGGTATTGG3' }\end{array}$ & $\begin{array}{l}\text { 5'GTCTCAACACGG } \\
\text { CCGACTG3' }\end{array}$ & 53 & 0.94 & N/A \\
\hline HSP90- $\alpha$ (17054) & $\begin{array}{l}\text { 5'TCAGCTGGAGTT } \\
\text { CCGTGCTT3' }\end{array}$ & $\begin{array}{l}\text { 5'TCGAAAGACGCC } \\
\text { CTTCTGG3' }\end{array}$ & 51 & 0.98 & 0.81 \\
\hline HSP60 (11881) & $\begin{array}{l}\text { 5'AAGTTGGCCGCA } \\
\text { AGGGAG3' }\end{array}$ & $\begin{array}{l}\text { 5'CGTGCAGAGTCT } \\
\text { TCCCATCC3' }\end{array}$ & 51 & 0.96 & 1.00 \\
\hline HSC70 (13955) & $\begin{array}{l}\text { 5'CAGTGGAGGACG } \\
\text { AGAAGCTG3' }\end{array}$ & $\begin{array}{l}\text { 5'TCTGTCTGTCCT } \\
\text { CTTCGCTGAT3' }\end{array}$ & 51 & 0.93 & 1.02 \\
\hline HSP70 (17285) & $\begin{array}{l}\text { 5'CTTCAGAGAGAC } \\
\text { AGGGTCTCCG3' }\end{array}$ & $\begin{array}{l}\text { 5'GAAGGCGTAGG } \\
\text { ACTCCAAGGA3' }\end{array}$ & 51 & 0.95 & 0.85 \\
\hline SIRT1 (03411) & $\begin{array}{l}\text { 5'GCAAACGCCTTG } \\
\text { AGACAGG3' }\end{array}$ & $\begin{array}{l}\text { 5'GCTCGACGTCTC } \\
\text { GTCCTCAG3' }\end{array}$ & 101 & 1.06 & 0.83 \\
\hline SIRT2 (05747) & $\begin{array}{l}\text { 5'ACCCAGGACAGT } \\
\text { TTAAGCCGA3' }\end{array}$ & $\begin{array}{l}\text { 5'TGTAGCAGCGCC } \\
\text { TCAAGTACC3' }\end{array}$ & 81 & 0.98 & 0.93 \\
\hline SIRT3 (15722) & $\begin{array}{l}\text { 5'CGAGGACAAGC } \\
\text { AGGACGC3' }\end{array}$ & $\begin{array}{l}\text { 5'GAGAGACGGTTT } \\
\text { GTCTGCACAG3' }\end{array}$ & 102 & 0.95 & 0.99 \\
\hline SIRT4 (01497) & $\begin{array}{l}\text { 5'CGCCATTGTGAA } \\
\text { CATTGGG3' }\end{array}$ & $\begin{array}{l}\text { 5'TTCAGCTCAGCC } \\
\text { AGGTGGTC3' }\end{array}$ & 51 & 0.95 & 1.04 \\
\hline
\end{tabular}

18s, 18s rRNA; EF-1 $\alpha$, elongation factor-1 $\alpha$, HSP, heat shock protein; HSC, heat shock cognate; SIRT, sirtuin. 
Table 2. Effect of cold acclimation on physical characteristics of G. aculeatus

\begin{tabular}{llll}
\hline $\begin{array}{l}\text { Temperature and time } \\
\text { point of harvest }\end{array}$ & Length $(\mathbf{c m})$ & Body mass $(\mathbf{g})$ & Condition factor \\
\hline $20^{\circ} \mathrm{C}$ (start) & $4.78 \pm 0.31^{\mathrm{A}}$ & $1.01 \pm 0.23^{\mathrm{A}}$ & $0.92 \pm 0.16$ \\
$8^{\circ} \mathrm{C}$ week 4 & $4.93 \pm 0.43^{\mathrm{AB}}$ & $1.13 \pm 0.21^{\mathrm{A}}$ & $0.94 \pm 0.09$ \\
$8^{\circ} \mathrm{C}$ week 9 & $5.43 \pm 0.25^{\mathrm{B}}$ & $1.63 \pm 0.19^{\mathrm{B}}$ & $1.03 \pm 0.10$ \\
$20^{\circ} \mathrm{C}$ week 9 & $5.32 \pm 0.49^{\mathrm{AB}}$ & $1.55 \pm 0.38^{\mathrm{B}}$ & $1.02 \pm 0.09$ \\
\hline
\end{tabular}

Table includes physical characteristics of animals used for measuring protein levels of HSPs. Physical characteristics

of animals used for measuring transcript levels have been reported previously (Orczewska et al., 2010). Condition

factor $=100 *$ body mass $(\mathrm{g}) *$ length $\left.(\mathrm{cm})^{-3}\right] ; \mathrm{N}=6$; Different letters represent significant differences among animals

harvested at different time points and temperatures $(\mathrm{P}<0.05)$. 